\title{
Natives and tourists of prosumer capitalism: On the varied pro-prosumer activities of producers exemplified in the Polish pop culture industry
}

\section{Piotr Siuda}

Kazimierz Wielki University, Poland

\section{Marek Troszynski}

Collegium Civitas, Poland

\begin{abstract}
This article pertains to the concept of prosumer capitalism, a term which refers to practices among companies of using consumers' unpaid work (prosumption refers to the mixing of consumption and production). In the literature, this type of capitalism has been treated generally; how pro-prosumer activities differ among producers has been overlooked. This article illustrates these differences by showing the ways in which Polish pop culture producers approach prosumption. The research was conducted through in-depth interviews with representatives from different Polish popular culture companies and the results show that prosumption orientation is determined by what is being produced - films, games, comics, books, television programmes, or music. Producers of video games and comics are most prosumption-oriented - in other words, they may be called 'natives' of prosumption - in contrast to 'tourists', such as producers of films, television programmes, and books. This article shows that developing the concept of prosumer capitalism requires that consideration as to the prosumer orientations of producers should be specified on a case-by-case basis.
\end{abstract}

\section{Keywords}

cultural industries, fandom, internet studies, popular culture, prosumer capitalism, prosumption

\section{Corresponding author:}

Piotr Siuda, Faculty of Administration and Social Sciences, Kazimierz Wielki University, Bydgoszcz, 85-092,

Poland.

Email: piotr.siuda@ukw.edu.pl 


\section{Funding}

This research has been undertaken by the Local Knowledge Foundation (Fundacja Wiedza Lokalna) and was financed by the Polish Ministry of Culture and National Heritage. It was allocated funding under the 'Observatory of Culture' programme.

\section{Note}

1. The following ranking lists were used:

- Films: http://www.boxofficemojo.com/intl/poland/yearly/?yr=2012\&p=.htm,

- Television: http://www.wirtualnemedia.pl/artykul/seriale-tvp-hitami-w-2012-roku-liderem-mjak-milosc

- Music: http://www.zpav.pl/rankingi/listy/top100/roczna.php

\section{References}

Antonio RJ (2015) Is prosumer capitalism on the rise? Sociological Quarterly 56(3): 472-483.

Banks JA (2013) Co-creating Videogames. London: Bloomsbury.

Baym NK and Burnett R (2009) Amateur experts: international fan labour in Swedish independent music. International Journal of Cultural Studies 12(5): 433-449.

Beer D and Burrows R (2010) Consumption, prosumption and participatory web cultures: an introduction. Journal of Consumer Culture 10(1): 3-12.

Beer D (2013) Popular Culture and New Media: The Politics of Circulation. New York: Palgrave Macmillan.

Brooker W (2002) Using the Force: Creativity, Community and Star Wars Fans. New York: Continuum.

Brooker W (2007) Everywhere and nowhere: Vancouver, fan pilgrimage and the urban imaginary. International Journal of Cultural Studies 10(4): 423-444.

Campbell C (2005) The craft consumer: culture, craft and consumption in a postmodern society. Journal of Consumer Culture 5(1): 23-42.

Cova B, Kozinets RV and Shankar A (eds) (2007) Consumer Tribes. London: ButterworthHeinemann.

Deuze M (2007) Convergence culture in the creative industries. International Journal of Cultural Studies 10(2): 243-263.

Frąckiewicz S (2013) Wielka gra małych gier [Big Game of Little Games]. Polityka [Politics]. Available at: http://www.polityka.pl/tygodnikpolityka/kultura/1534247,1,swiatowe-sukcesypolskich-gier.read (accessed August 2016).

Ito M (2007) Technologies of the childhood imagination: media mixes, hypersociality, and recombinant cultural form. In: Karaganis J (ed.) Structures of Participation in Digital Culture. New York: Social Science Research Council, pp. 31-34.

Jenkins H (2004) The cultural logic of media convergence. International Journal of Cultural Studies 7(1): 33-43.

Kozinets RV (2010) Netnography: Doing Ethnographic Research Online. London: Sage.

Long GA (2007) What Is Transmedia Storytelling: Business, Aesthetics and Production at the Jim Henson Company. Available at: http://cms.mit.edu/research/theses/GeoffreyLong2007. pdf (accessed August 2016).

Meisler A (1995) Television: when J. R. was shot the cliffhanger was born. New York Times. Available at: http://www.nytimes.com/1995/05/07/arts/television-when-j-r-was-shot-the-cliffhanger-was-born.html?pagewanted=all (accessed August 2016). 
Morrow G (2009) Radiohead's managerial creativity. Convergence: The International Journal of Research into New Media Technologies 15(2): 161-176.

Nakajima S (2012) Prosumption in art. American Behavioral Scientist 56(4): 550-569.

Postigo H (2007) Of mods and modders: chasing down the value of fan-based digital game modifications. Games and Culture 2(4): 300-313.

Ritzer G and Jurgenson N (2010) Production, consumption, prosumption: the nature of capitalism in the age of the digital 'prosumer'. Journal of Consumer Culture 10(1): 13-36.

Ritzer G, Dean P and Jurgenson N (2012) The coming of age of the prosumer. American Behavioral Scientist 56(4): 379-398.

Siuda P (2012) Kultury prosumpcji [Prosumption Cultures]. Warsaw: ASPRA-JR.

Siuda P, Bomba R, Kaminska M, Stunza GD, Szylar A, Troszynki M et al. (2013) Prosumption in the Pop Industry: An Analysis of Polish Entertainment Companies. Warsaw: Collegium Civitas Press.

Tapscott D and Williams A (2006) Wikinomics: How Mass Collaboration Changes Everything. New York: Penguin Group.

Taylor JR (2009) Convention cosplay: subversive potential in anime fandom. MA thesis, University of Oregon. Available at: http://circle.ubc.ca/handle/2429/7116 (accessed August 2016).

Terranova T (2000) Free labour: producing culture for the digital economy. Social Text 18: 33-58. Théberge P (2005) Everyday fandom: fan clubs, blogging, and the quotidian rhythms of the internet. Canadian Journal of Communication 30(4): 485-502.

\section{Author biographies}

Piotr Siuda is Assistant Professor and Dean at the Faculty of Administration and Social Sciences at Kazimierz Wielki University in Bydgoszcz (Poland). His research interests include the sociology of culture, prosumption, social aspects of the internet and media literacy. He is the author of five books in Polish, including Religion and the Internet and Prosumption Cultures.

Marek Troszynski holds a PhD in sociology. He is a chair of the Local Knowledge Foundation and an Assistant Professor at Collegium Civitas in Warsaw. He is a researcher with experience in projects in the field of participation in culture and computer-mediated communication. 


\section{Introduction}

In their highly influential article, "Production, Consumption, Prosumption: The nature of capitalism in the age of the digital 'prosumer'," George Ritzer and Nathan Jurgenson (2010) announced the advent of prosumer capitalism. According to Ritzer and Jurgenson, the “age of the prosumer" has arrived (cf. Ritzer, Dean, Jurgenson, 2012)_ “prosumers” being people who are both consumers and producers. In prosumer capitalism, the traditional division between production and consumption, which dominated previous eras and determined social life trajectories, has been severed.Prosumption has advanced to a leading position for two basic — and interrelated—reasons (cf. Ritzer, Dean, Jurgenson, 2012). The first reason may be considered changes in the production system, inclusive of a variety of processes. For example, there is what has been called the decline in factory work; production is no longer perceived as it used to be. Today, production need not result in anything tangible, physical or material. Producing has begun to resemble immaterial labor, which means that it no longer takes place in a closed factory space but in so-called social factories, providing ideas and notions rather than things per se (Terranova, 2000).

If we assume that production is changing in the above-mentioned way, it is easier to understand why the consumer may be prompted to work. Practically, each of us can enter the social factory and undertake activity for a particular brand; each of us may be a creator of the meanings that surround such brands. In addition, if proper technological tools are made accessible to us, we may be able to translate our ideas into more tangible creations.

Technological progress is the second reason for the increasingly strong position of prosumption. Nowadays, due to the Internet, every consumer is provided with a set of tools, by means of which one may become a producer. For the development of prosumption, the Internet is particularly important, especially the aspect referred to as Web 2.0. (Beer, Burrows, 2010; Ritzer, Jurgenson, 2010). In the Web 2.0 context, users provide content, as occurs with 
many online sites. It is users who, through their activity, co-create social networking sites such as Facebook, Twitter, YouTube, and many others. Internet users' creative activities are not limited to these sites but are instead, to a varied extent, visible throughout the Internet.

In the literature, these Internet prosumer trends have been referred to in various ways. Authors have addressed how buyers co-create product value (Beer, Burrows, 2010), wikinomics (Tapscott, Williams, 2008), and the "craft consumer" (Campbell, 2005). Researchers from cultural studies and the sociology of culture have focused primarily on the bottom-up activities undertaken by prosumers and have perceived prosumption from this bottom-up perspective. Obviously, such a perception is natural-prosumers working for free are the essence of prosumption. The way to find out about the developing influence of prosumption is to "speak" to those who are prosuming.

However, if one views prosumption through the theory of prosumer capitalism, it has to be admitted that producers' activities are also important. It is key for prosumption to be stimulated by producers themselves. Thus, prosumption must be viewed as a specific marketing approach dependent upon engaging consumers in the production process. An orientation toward prosumption means stimulating and using consumers' activities and involvement in order to gain access to many people willing to work for free for a brand. Thus, addressing prosumption begs an interrogation into producers' prosumption orientation -in other words, the activities they undertake to stimulate consumers to work.

One irony is that even those researchers who have defined prosumption exclusively as bottom-up activities undertaken by prosumers have also sensed the important role that producers play in the development of prosumption. For example, Robert V. Kozinets (2010: 176-177) defined the relations between prosumers and corporations in two contradictory ways. On the one hand, he emphasizes prosumers' subversion of the activities of for-profit companies; on the other, he enumerates many accounts of flourishing cooperation. Kozinets 
stressed that both approaches are too extreme because the interrelations between prosumers and producers are full of tension, dialogue, paradoxes, and compromises. Nevertheless, the fact remains that corporations exert a substantial influence on contemporary bottom-up prosumer trends (cf. Cova, Kozinets, Shankar, 2007).

Importantly, these trends are frequently characterized through examples from the sphere of popular culture (cf. Beer, 2013; Siuda, 2012). In this sphere, the prosumer nature of the Internet may be used by producers because of the strength of the interrelation of the Internet and popular culture; furthermore, the two share many common points (cf. Beer, 2013). Obviously, prosumption also exists in other areas of social life, both in various sectors of the economy and in regard to less commercial phenomena, such as, for example, art (cf. Nakajima, 2012). In spite of that, it is popular culture that is appropriate to illustrate prosumption.

In this article, we use examples from popular culture. We also intend to "liberate" ourselves from the perspective that prosumption is exclusively a matter that pertains to the bottom-up activities undertaken by prosumers. Rather, we focus on producers; this area of research has been highly neglected, especially in cultural studies and the sociology of culture. There have already been studies which outlined prosumption trends across different creative industries (journalism, advertising, public relations, etc.; Deuze, 2007) or focused on relations between consumers and producers as regards particular industries (for example, video games; Banks, 2013). Furthermore, the literature contains a lot of works on prosumption as capitalistic exploitation. Large companies are meant to be preying on free labor of those who have got involved in consuming to such a degree that they also want to produce something as amateurs (cf. Antonio 2015). However, the topic still seems to be neglected. The focus on particular industries results in prosumption not being approached in a comprehensive way, and presenting it solely in terms of exploitation entails the omission of 
many nuances. Hence, we are lacking studies attempting to capture the various shades of different producers' attitudes towards prosumption.

This article approaches the recently fashionable subject of consumer activity from another angle and describes the extent to which contemporary Polish pop culture producers opt for consumer support. This approach differs from the vast majority of contemporary research as, rather than focusing on the bottom-up (consumer) level, we have focused on the top-down decision-making spheres that influence the contemporary Polish popular culture scene.

In the literature, ample studies have already addressed the differences in bottom-up prosumer activities based on examining the fandoms of various popular culture texts (cf. Cova, Kozinets, Shankar, 2007). A similar analysis of the activities undertaken by producers is warranted. Our aim is to show that the activities undertaken by producers to stimulate prosumption cannot be defined in universal categories and treated in a general way-in other words, such activities cannot be defined in terms of a universal mechanism for the circulation of popular culture. The presented empirical example proves the complicated nature of the activities undertaken by producers and thus tells us something about the varied nature of prosumer capitalism itself.

The article presents the research project, Prosumption in the Pop Industry: An Analysis of Polish Entertainment Companies (Siuda et al., 2013) which was implemented by the Local Knowledge Foundation (Fundacja Wiedza Lokalna) and was awarded a grant by the Polish Ministry of Culture and National Heritage. The project was conducted from March to December 2013 with the objective of determining to what degree so-called prosumption orientation is disseminated among Polish pop culture producers, i.e., producers of films, television programs, books, comics, games, and pop music. For clarity, it is worth stressing that by producers, we mean the companies that oversee the process of production and not 
particular artists.

This article presents results obtained through in-depth interviews with Polish pop culture producers. In the course of these interviews, we determined to what degree the selected Polish companies were oriented towards developing pro-prosumption activities and what results they achieved. In addition, we determined the reasons a company would opt for prosumption. In light of the earlier mentioned objective, we indicate that in regard to the stimulation of prosumption by popular culture producers, the landscape is not uniform. We determined that prosumption orientation is dependent on the type of pop culture content being produced.

\section{Method: on the model and in-depth interviews}

The starting point for our analysis was the assumption that there are multiple dimensions to stimulating prosumption practices. We began the project by identifying those dimensions through a review of the literature pertaining to trends connected with prosumption. This led us to the construction of a model for pro-prosumption activities in the pop culture industry. This is the model on which we have concentrated our analyses to determine whether Polish producers undertake the activities indicated. The model is divided into what we have called modules and standards. The former comprise the most general characteristics of proprosumption practices, whereas the latter describe them in more detail. Each standard has been supplemented with a number of examples. The model is presented in Table 1; please note that next to each standard, we have listed only two examples from the many that we have identified (the full model encompasses several pages, with a dozen or so examples listed next to each standard). 
Table 1. The Model for Pro-prosumption Activities of Pop Culture Industry

\begin{tabular}{|c|c|c|}
\hline Modules & Standards & Examples (two per each standard) \\
\hline \multirow{4}{*}{$\begin{array}{l}\text { (M1) Depending } \\
\text { on consumers' } \\
\text { productions. }\end{array}$} & \multirow{2}{*}{$\begin{array}{l}\text { (S1) Stimulating amateur } \\
\text { productions connected with } \\
\text { the official text (Brooker, } \\
\text { 2002). }\end{array}$} & $\begin{array}{l}\text { Do the producers organize fan fiction (short stories } \\
\text { by fans) competitions for consumers? }\end{array}$ \\
\hline & & $\begin{array}{l}\text { Do the producers provide free access to certain } \\
\text { content (film previews, soundtrack, character } \\
\text { templates, full texts, etc.) with a view to their creative } \\
\text { use by consumers? }\end{array}$ \\
\hline & \multirow[t]{2}{*}{$\begin{array}{l}\text { (S2) Using amateur } \\
\text { productions in official pop } \\
\text { text. }\end{array}$} & $\begin{array}{l}\text { Do the game producers assume the possibility of } \\
\text { releasing games created on the basis of mods } \\
\text { (amateur modifications) made by the gamers } \\
\text { (Postigo, 2007)? }\end{array}$ \\
\hline & & $\begin{array}{l}\text { Do the producers use work by consumers (for } \\
\text { example, cosplay, i.e., dressing up as favorite } \\
\text { characters) while organizing events to accompany } \\
\text { text promotion (Taylor, 2009)? }\end{array}$ \\
\hline \multirow{6}{*}{$\begin{array}{l}\text { (M2) Stimulating } \\
\text { and using } \\
\text { consumer activity } \\
\text { online and offline. }\end{array}$} & \multirow{2}{*}{$\begin{array}{l}\text { (S1) Initiating virtual } \\
\text { communities of consumers } \\
\text { (Théberge, 2005). }\end{array}$} & $\begin{array}{l}\text { Do the producers create official websites connected } \\
\text { to pop culture products? }\end{array}$ \\
\hline & & $\begin{array}{l}\text { Do the producers promote pop culture products on } \\
\text { social media (e.g. on Facebook, by setting up fan } \\
\text { pages)? }\end{array}$ \\
\hline & \multirow[t]{2}{*}{$\begin{array}{l}\text { (S2) Monitoring virtual } \\
\text { communities and stimulating } \\
\text { activities within them } \\
\text { (Théberge, 2005). }\end{array}$} & $\begin{array}{l}\text { For their activities, do the producers take into } \\
\text { account texts rankings and reviews created by } \\
\text { Internet users? }\end{array}$ \\
\hline & & $\begin{array}{l}\text { Do the producers use word-of-mouth marketing to } \\
\text { advertise certain text (e.g. starting threads on bulletin } \\
\text { boards; stimulating discussions on specific } \\
\text { subjects)? }\end{array}$ \\
\hline & \multirow[t]{2}{*}{$\begin{array}{l}\text { (S3) Organizing offline } \\
\text { events. }\end{array}$} & $\begin{array}{l}\text { Do the producers engage in organizing fan } \\
\text { conventions and to what extent and on what terms } \\
\text { (Taylor, 2009)? }\end{array}$ \\
\hline & & $\begin{array}{l}\text { Do the producers organize offline events for } \\
\text { consumers (contests, auctions, trips to places } \\
\text { connected with texts, urban games referring to texts, } \\
\text { etc.) (Brooker, 2007)? }\end{array}$ \\
\hline \multirow[t]{3}{*}{$\begin{array}{l}\text { (M3) Inspiring } \\
\text { affective } \\
\text { (emotional) } \\
\text { attitude in } \\
\text { consumers. }\end{array}$} & \multirow{2}{*}{$\begin{array}{l}\text { (S1) Creating transmedia } \\
\text { storytelling, in which various } \\
\text { manifestations of the } \\
\text { presented world are shown } \\
\text { on many media platforms } \\
\text { such as film, TV series, } \\
\text { book, comic book, etc. } \\
\text { (Long, 2007). }\end{array}$} & $\begin{array}{l}\text { Do the producers creating transmedia storytelling } \\
\text { associate (link) different media platforms so that they } \\
\text { cannot be consumed separately (e.g. reading a book } \\
\text { contributes to the understanding of what was seen at } \\
\text { the cinema)? }\end{array}$ \\
\hline & & $\begin{array}{l}\text { Do the producers - constructing the narrative layers } \\
\text { of certain text - focus more on building and enriching } \\
\text { the presented reality than on developing the } \\
\text { protagonist's plot? }\end{array}$ \\
\hline & $\begin{array}{l}\text { (S2) Relying on textual } \\
\text { techniques which result in }\end{array}$ & $\begin{array}{l}\text { Do the producers use the so-called cliffhangers, i.e., } \\
\text { endings (of episodes, films, books) that suspend }\end{array}$ \\
\hline
\end{tabular}




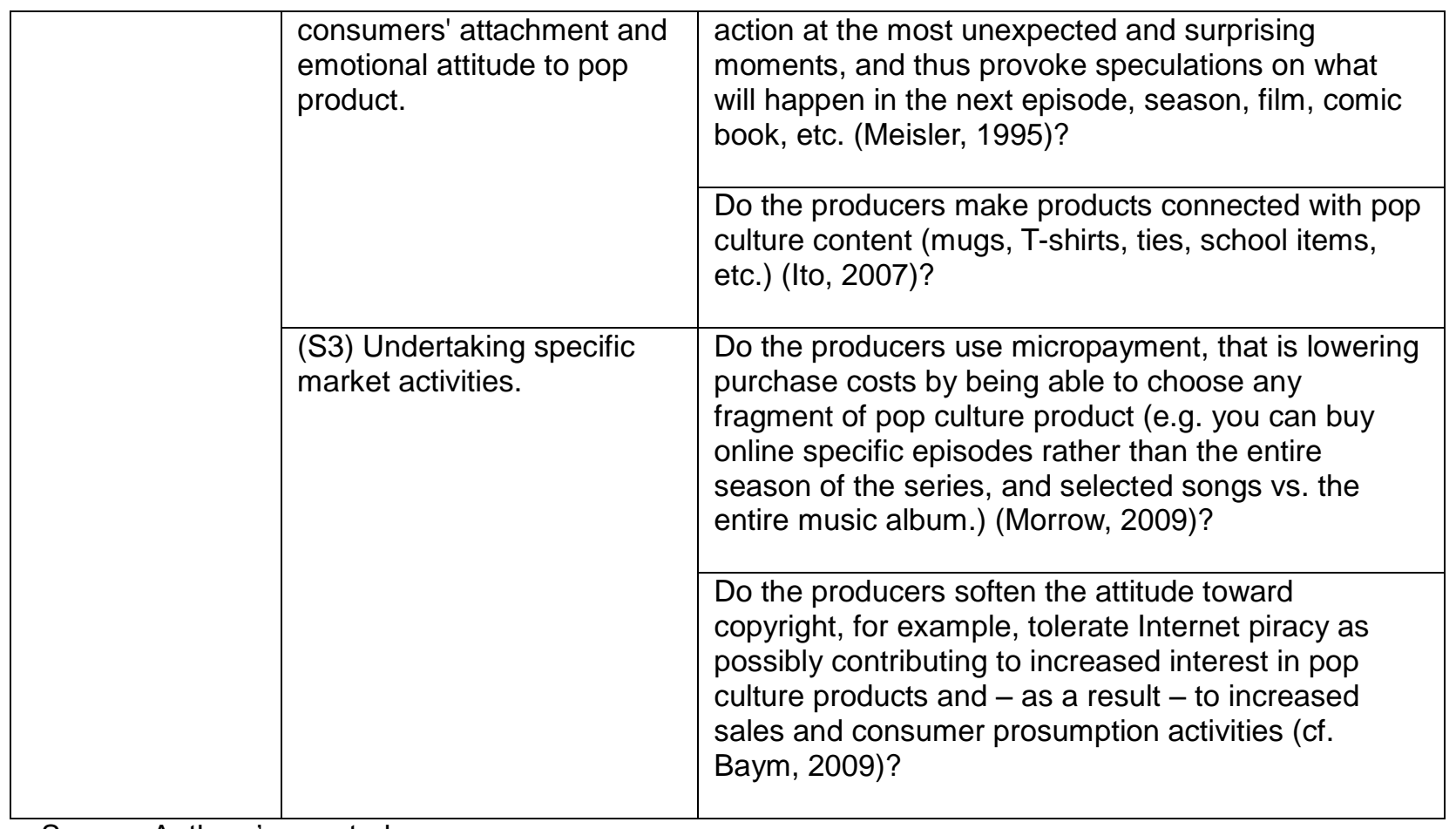

Source: Authors' own study

In this article, the results of the project are reported accompanied by symbols in brackets-for example, “(M1, S1)." These symbols reference activities that appear in the model. The letter " $\mathrm{M}$ " indicates the module and " $\mathrm{S}$ " indicates the standard; the numbers next to these letters indicate the number of the module or standard.

The modules, standards, and examples were used to develop the in-depth interviews. The target group selected for the interviews comprised decision-making employees from companies within the entertainment industry; specifically, we targeted departments in these companies that are most influential in implementing prosumption orientation. The interviews were conducted with presidents, CEOs, supervisory board members, marketing and PR department directors, purchasing and distribution department directors, and sales department directors.

One of our objectives was to contact the representatives of the most influential companies. We decided that the interviews should be conducted with the producers of particularly important pop texts, identified as follows: 
- Games: Wiedźmin 2 (The Witcher 2: Assassins of Kings), Dead Island, Sniper:

Ghost Warrior

- Publications (comics and books): the Wilq comics, the Jeżycjada book series (by Małgorzata Musierowicz), the Żaby $i$ anioły book series (Frogs and Angels, by Katarzyna Grochola)

- Films: Hans Kloss: Stawka większa niż śmierć (Hans Kloss: Stakes Larger than Death), Jesteś Bogiem (You are God), Mój rower (My Bicycle)

- TV series: Pierwsza miłość (First Love), Ranczo (The Ranch), Mjak miłość (L for Love)

- Music bands: T.Love, Hey, Luxtorpeda

We selected a set of pop texts created or still in progress (as series) as of 2012 that were produced by Polish companies. With regard to films, television, and music, particular titles were chosen based on their popularity or to ensure producer diversity. We followed various rankings (shown below) moving from the "top" of a list, but we also considered who had created these texts. For example, if $\mathrm{X}, \mathrm{Y}$ and $\mathrm{Z}$ were ranked the top three, but $\mathrm{X}$ and $\mathrm{Y}$ were produced by the same company and $\mathrm{Z}$ by a different one, then $\mathrm{X}$ and $\mathrm{Z}$ were selected for the study. The following ranking lists were used:

- Films: http://www.boxofficemojo.com/intl/poland/yearly/?yr=2012\&p=.htm,

- Television: http://www.wirtualnemedia.pl/artykul/seriale-tvp-hitami-w-2012-roku-liderem$\underline{\text { m-jak-milosc }}$

- Music: http://www.zpav.pl/rankingi/listy/top100/roczna.php 
It should be noted that the described method of selection was not always applied. With films, we decided to choose the film Hans Kloss: Stawka większa niż śmierć. Independent of the rankings, we concluded that this picture was important due to the special place it holds in Polish pop culture (as it refers to the cult series Stawka większa niż zycie [Stakes Larger than Life]). The same applied to games: we decided to study those that were leading in various rankings but had not necessarily been produced in 2012. A similar situation occurred with publications. For example, we decided that Jeżycjada (a series of books by Małgorzata Musierowicz) was a good choice as it has been on the Polish market for many years.

The in-depth interviews were conducted with representatives from the companies producing the aforementioned pop products, balanced by interviews with representatives from smaller enterprises whose titles were not as popular as those listed above, in order to obtain a relatively comprehensive picture of the Polish entertainment sector. Naturally, the research was not based on a representative sample.

In summary, we identified 20 employees from Polish companies producing five types of pop product (see Table 2). Representing a particular sector of the pop culture industry was the most important variable to diversify the population we were studying. The sectors surveyed included television , cinema, video games, publications (books and comics), and music (music performers). It is worth noting that in Poland, the market is not centralized. Unlike in the USA, it is not common for one company to produce several types of content (cf. Jenkins, 2004). 
Table 2. Sample of In-Depth Interviews

\begin{tabular}{|l|l|l|}
\hline Interview number & Industry & City \\
\hline 103 & music & Warsaw \\
\hline 101 & music & Warsaw \\
\hline 102 & music & Warsaw \\
\hline$I 15$ & games & Warsaw \\
\hline$I 14$ & games & Warsaw \\
\hline$I 13$ & games & Warsaw \\
\hline 120 & games & Warsaw \\
\hline 105 & film & Warsaw \\
\hline 104 & film & Warsaw \\
\hline 107 & film & Warsaw \\
\hline 106 & film & Warsaw \\
\hline 108 & publishing houses & Cracow \\
\hline$I 11$ & publishing houses & Warsaw \\
\hline$I 10$ & publishing houses & Warsaw \\
\hline 109 & publishing houses & Warsaw \\
\hline$I 12$ & publishing houses & Warsaw \\
\hline$I 17$ & television & Warsaw \\
\hline$I 18$ & television & Warsaw \\
\hline$I 19$ & television & Warsaw \\
\hline$I 16$ & television & Warsaw \\
\hline
\end{tabular}

Source: Authors' own study

\section{Results}

In categorizing the respondents' statements, we identified several thematic areas which are discussed as follows, beginning with the understanding of the notion of "prosumption" and an assessment of prosumption trends in the future. Subsequently, we address the issues of communicating with consumers (prosumers), particular pro-prosumption activities, and copyright. Finally, we briefly discuss the obtained results and summarize the study.

It is necessary to note that although we have subdivided this section of the article, all standards and examples from the aforementioned model of pro-prosumption activities in the pop culture industry were discussed in interviews. Some examples included in the model were discussed by our respondents at length, whereas others were mentioned briefly or not at all. The fact that certain topics emerged in the course of interviews and others did not is a natural indication of the state of prosumption orientation in Polish pop culture companies. In some sections of this article, we quote statements from the respondents. The statements are labeled 
by the number of the interview from which they were taken (I1-I20).

\section{Prosumption-perception and future of the phenomenon}

Prosumption orientation is determined by the type of content a company produces. To begin, this section presents the sectors in which attitudes toward stimulating pro-prosumption activities are most skeptical.

With regard to the cinema, it would seem that due to the nature of cinematic production - in which every film necessitates big budgets and long production schedulesaudience participation in actual film production is especially difficult. This was also the opinion of our interlocutors; it may be paraphrased as "we are the artists, we create art, and this requires skills, money, and talent." While there was no questioning of the basic rules of marketing or the necessity of learning about the audience's tastes, it was stressed that there was no room for creative activity or participation by amateurs in the production process or even in film promotion (M1, S1; M1, S2).

The interviewees drew our attention to an issue that is closely connected to the above: the length of time between the moment a film is conceptualized, the beginning stages (for example, writing the script), completion, and distribution. Keeping consumers in such a project for so long and counting on their help, advice, and creative work would be difficult. This is problematic in that the majority of marketing budgets are spent after premiere dates are set; thus, most production occurs "behind the scenes," away from a media that could direct the audience' s attention toward the film as it is being made.

Our study revealed that in the music industry, the relevant questions are as follows: What is next? What are the new models of distribution? What channels of communication with the consumer, standards of transmission, and methods for selling music will be popular in the future? The answers to these questions determine the range of pro-prosumption 
activities. According to our interlocutors, technology will determine the standards of cooperation with consumers:

I say YouTube. In the States, this medium is already highly developed. But I think that in Poland, YouTube will be hugely developed yet. This is what I'm sure of, other things I'm not. Sure, I might have mentioned a few things, but YouTube, for sure, in the next year or two, there is tons to be done. It's going to generate profits, it's going to generate various events, and it's going to develop massively (I22).

According to interviewees from the largest Polish TV stations, television production is too complex an activity to be ceded to amateurs - it is the domain of professionals (M1, S1; M1, S2).However, the TV interviewees' reflections on the future of sale models and marketing activities were highly interesting. The respondents believed that there would be considerable changes if we take into account the Internet as the next platform for the transmission of television content. The significance of the Web derives from the ability to establish immediate contact with the viewer and gather instant information on changes in the audience and individual viewers' preferences, as well as the opportunity to provide any content at any time. These qualities are presumed to fundamentally change the model of communicating with the viewer and enable them to decide on programming. As was stressed by the interviewees, we are on the eve of a significant change in the philosophy of television transmission. If there is a prosumption revolution waiting to emerge somewhere, it is here. The tools to generate content are being handed over to consumers.

However, representatives from book publishers conceived of the future of prosumption in a markedly differently way to those in music or television. For book companies, the 
development of the technology that is directly connected with publishing activities is not of substantial importance. What seems to be more important is the popularity of social media:

If I were to indicate any trends or even wonder what the future may look like, then for sure, social media and the Internet will play an increasingly bigger role. This will be based on mutual benefit; the reader will be able to obtain bonuses for being active. In addition, we as the producers will know our market better, so our activities will be targeted, well-thought out, and able to reach a larger group of potential readers(I08).

When it comes to publishing houses, it is worth separating the companies that publish books (i.e. novels) from those that publish comic books. Pro-prosumption activities are inherent in the comic realm, i.e., they have accompanied publishers from the beginning of their operations. This was effectively explained by one of our interlocutors:

This is a specific industry, a specific section of publishing, where I really get the impression that fans are really close to the publishers [and] authors... What I mean here is that producers are coming from... fandoms, where the line between the creator and the fan... is very thin (I09).

Moving away from comics, it may be said that the video game industry is a model field for pro-prosumption activities, one in which all producers use various mechanisms for engaging consumers in product promotion. The specificity of gamers (who all use the Internet and are, most frequently, young people) makes consumers' involvement in promotion of games much easier to achieve. Consumers are perceived as a "community"in which the 
members communicate and collectively produce and interpret meanings. The producers are aware that every mistake they make will be noticed and comprehensively commented on.

\section{Communication with the consumers}

The manner in which contact with consumers is initiated varies depending on the industry. As was previously discussed, this type of contact is particularly important for comic publishers. The interviewees from this group frequently indicated the significance of fandoms (fan communities) in shaping positive brand images; at the same time, they stressed that it is often the fans who are first to initiate discussions on social media, primarily Facebook (M2, S1).

The comic companies are aware of the fact that it is crucial for consumers to feel as though they are a significant element of the brand. Consequently, comic producers also referred to their "naturalness" and "honesty" in communicating with consumers. According to the respondents, this attitude affects their audience: they do not perceive the company's activities as part of a marketing campaign but as an element of a corporate culture that suggests that publishers are genuinely engaged in the products they have created.

Video game producers indicated that their most intensive contact with consumers took place over social media (Facebook, Twitter, etc.). Game publishers often indicated that they were aware of the importance of incessant and properly moderated discussion (M2, S1; M2, S2).

Significantly, interviewees from the game industry also mentioned the importance of personal, even friendly, contact with the audience (M2, S2). Their aim is to initiate a partnership with the gamers; it is important to give the consumers an opportunity to have an impact on the final product that appears on the market. Gamers have the impression that they themselves have participated in creating the game - that it is not only something imposed on them by the producers, but the result of collaborative, collective work (M1, S1; M1, S2; M2, S2). This enables the consumers to feel that the producer is one of them-a gamer devoted to 
creating new content. This strategy is highly beneficial:

You know, this makes the gamers feel they are our mates... Yes, they're somehow our partners because we wouldn't be able to create without them; this is valuable and market-wise. They are very much driving us (I15).

The specific nature of the game industry also relies on the gamer conventions that are frequently held, which provide a perfect opportunity to strengthen or maintain contact initiated through electronic media (M2, S3). At numerous conventions and fairs, collective discussions and playing sessions are held. Producers are willing to use this form of promotion. In their statements, the interviewees stressed the importance of the consumer community in creating an image both for particular titles and of the industry as a whole

Music producers are also aware of the importance of an Internet presence. Thus, they use various channels of communication which enable them to maintain contact with consumers and post diverse content via feeds to initiate discussions and provide photos and free music samples. It is interesting to note that music publishers are becoming less likely to use their official brand websites or maintain bulletin boards. Our interviewees noted that the best way to build a bond with consumers is through Facebook (M2, S1).

Film producers would like to use the opportunities afforded by the Web to a larger extent, but they do not have the budget for such activities. The respondents stressed that in order for such communication strategies to be efficient, they would have to be initiated in the pre-production period; however, only key players in the United States or Western Europe can afford this.

The film industry engages consumers in co-creating products to a smaller extent than games or comic publishers. The interviewees admitted that they do not, on a daily basis, 
manage communications with their audiences. The producers realize that films are modified or parodied by audiences. However, this realization does not imply that special activities aimed at stimulating further amateur production are warranted (M1, S1). As for being present in social media, film producers are just learning about this kind of contact with the viewer, and thus, they treat it more like a vehicle for new content promotion (M2, S1) rather than as an instrument for initiating dialogue with the audience (M2, S2).

Non-standard forms of communication are more often used by book publishers. They have come to use increasingly varied forms of promotion: they now publish announcements in many places on the Internet (Facebook, Twitter, YouTube) and have noted that this strategy has garnered benefits (M2, S1). Although "fans do not yet decide the fate of the protagonist, like in video games" (I08), there appear to be some interesting ideas for promotion among publishers. Some producers place QR codes on the back covers of their books that lead to galleries of, for example, photos of the author. There are plans to make it possible, in the future, to display alternative endings to books that can be accessed through QR codes (M3, $\mathrm{S} 1 ; \mathrm{M} 3, \mathrm{~S} 2)$. Today, the basic obstacle for implementing this idea is that the authors themselves that are rather unwilling to agree to this kind of cooperation, as it requires additional work.

\section{Other pro-prosumption activities}

We have discussed the activities connected to communicating with consumers (mainly via social media). It is worth noting that there have been examples of more comprehensive ideas for involving consumers, but according to entrepreneurs, budgetary limitations are the basic problem that impedes the ability to fully implement these ideas. Citing foreign companies that successfully carry out marketing activities, the respondents often said that they would willingly apply some of these activities if they had sufficient funds. 
Despite the lack of money, various pro-prosumption activities are undertaken. Fan fiction (amateur short stories by fans) and music performance competitions are very popular (M1, S1). One of the book publishers cited the example of a video blog to be developed in the future to enable readers to post videos in which they describe the latest publications, provide reviews, or make recommendations:

For example, we once organized a competition... Facebook users were asked to complete speech bubbles next to characters with their own text. We tried to develop video blogs so that the readers could record themselves with either their mobiles or their cameras and post videos of themselves talking about a book on the Web. This is an area that hasn't been explored to the full extent yet and it's a bit of an unknown field, but we are thinking about it and we have made the first attempts, which have been somewhat successful (I08).

Comic book publishers also organize various competitions (M1, S1). In one interview, a representative from one of the comic publishing houses discussed the creation of a blog that has become the platform for notifying readers about contests (M2, S1; M2, S2). The respondent mentioned this as an example of an activity that is significant from the point of view of the company and has not yet been undertaken by any other producer.

What also happens is that consumers' opinions serve as inspirations in text distribution for comic publishers. This was the case at one of the publishing houses after they posed a question on the Internet about the price of a particular comic book before issuing it (M3, S3):

This is an American comic book, I'm not going to get into details about it, 
but the case is that generally, American comics published on the Polish market are expensive. It's a matter of the rights and materials that are necessary to produce such a comic book. One book would be rather expensive, it would be about, I guess 60 zloty, which is around \$20, \$23 US dollars, and we could divide the book into two for 35 zloty each. So we asked a question online. We got feedback, people spoke their minds... and people were quite actively sharing their thoughts; they made the decision. We agreed that it was worth dividing that book into two (I10).

In the video game industry, the most engaged consumers are often asked to test an almost finished game before it is released into the market (M2, S2). Based on their suggestions and comments, the producer makes changes and alterations. Game publishers are also flexible when it comes to payment (M3, S3), i.e., they want the gamers to have the chance to declare the amount they are ready to pay for the product and to be able to express their opinion on the form of payment. Game producers also try to promote fan fiction (M1, S1). According to the respondents, this type of consumer activity may reveal a great deal about which title is the most popular.

Television producers point at hybrid television as the most likely solution to allowing interactive participation with the audience. In this scenario, the viewer may "go deeply into" the pop text at a much greater level than is possible when watching the program on classic television:

We are the only TV station, the only broadcaster with the new "hybrid television." Hybrid TV is a combination of television and the Internet. Here, interactivity is by all means possible since at the moment a program with the 
"hybrid content" is broadcast, a special piece of information appears to indicate that we are connected to the Internet, and by using a remote control, we may gain insight into this content on a different server (I17).

Music publishers, citing positive examples from their field, referred to "something that stands out in the Polish market" (I01) — a record label that turned a YouTube channel into a type of Internet radio station (M2, S1). Another record label designed their own fashion and gadget line connected with digital music sales (M3, S2).

\section{Prosumption and copyright}

Depending on the industry sector, the understanding of the problem of copyright (M3, S3) varies substantially. In comparing our interviewees' opinions, we noticed a liberal attitude toward copyright in connection with business operations in new media, i.e., the Internet. These producers overlook intellectual property infringement because they have accepted reality and have understood the difficulty of enforcing copyright law. At the same time, entrepreneurs are aware that the issue of copyright is widely discussed by consumers. Combined with the ease of copying content - the predominant characteristic of the digital world - it is clear that producers themselves must change their way of thinking with regards to intellectual property when their works are distributed on the Internet. In reviewing our respondents' statements, we assigned them to the "digital world" (liberal attitude toward copyright) or to the "analog world" (conservative attitude).

The music industry representatives demonstrated the "traditional" approach to intellectual property. Paraphrasing our interlocutors: "we conduct business in accordance with certain specified rules, according to an accepted business model, and we demand that our clients abide by the same rules": 
It means we are restrictive because the business model of a record label assumes that people buy the record we invested money to make and that this money gets returned... Also, if we see that the fans, or simply, I don't know, random people put whole albums on YouTube, then, unfortunately, we have to take what they posted down (I02).

An even more restrictive approach is visible in the film industry. Pursuing copyright violations and detecting the unauthorized use of films are considered a basic part of the responsibilities of the marketing department in various companies. In an interview with a representative from a film studio, there appeared a term that is key to understanding the way film producers think: "ordering the Internet." The aim of this is to achieve the "old order" on the Web-completely eliminating content that results in license infringement:

The publishing industry representatives (books and comics) stressed their role as mediators between authors and readers. They cited the need to pursue restrictive policies regarding digital media use to safeguard authors' interests. One of our interviewees, a representative from an established, 60-year-old publishing house, explained this as follows:

We are an example of a publishing house that respects certain rules; contracts and copyrights are things that are sacred to us... Obviously, we disapprove of piracy and publishing whole books on the Internet (I08).

Sometimes producers decide not to claim their rights, as they are aware that an attempt to exercise them may ultimately do more harm than good. Interestingly, displaying an understanding of activities that are illegal may result in numerous advantages connected with 
reputation. This was the opinion of representatives of companies in the game industry. In order for this strategy to be effective (that is, in increasing sales), it is necessary to think about consumers as constituting communities.

For television broadcasters, copyright and piracy problems are not directly related with "ordinary" users and the copying of content. Disorganized activities cannot seriously impede those producers' activities. Drawbacks pertaining to intellectual property are rather associated with loopholes in the law that enable other business entities to take advantage of products made by TV stations. The issue here is that some programs are illegally rebroadcast on the Internet. TV producers see piracy as "unfair business, and not as fan activities" (I16).

In the context of copyright infringement, the respondents demonstrated diverse attitudes toward consumers' amateur productions. The "digital" interviewees stressed that it is important to take advantage of consumers' activities, as such activities provide free advertising. Opinions among "analog” interviewees were quite different. Furthermore, "digital" interviewees indicated that it is necessary to relinquish a portion of income as a way of investing in cooperation with consumers for future profit:

Our approach is that we allow them to use many elements from our game, I don't know, for example, music for non-commercial fan productions and for productions that we are fully aware of (I13).

\section{Discussion}

The study shows that how prosumption is stimulated is highly dependent on industry. By comparing our interviewees' opinions, we identified two groups whose representatives demonstrate dissimilar approaches to pro-prosumption activities; it is, however, worth noting that these categories are analytical categories and were conceived as ideal types. Furthermore, 
our aim was not to create categories to serve as universal indicators of prosumer orientations among producers beyond Poland; these categories were formulated as a result of analyzing the collected empirical material. Thus, this division illustrates only what is happening in Poland. The categories presented here should not be directly applied to analyzing other markets or other contexts. Moreover, even in the Polish context, it is worth realizing that the two categories are like poles on a continuum and not clearly separate-it is difficult to draw a clear line between the two groups. It seems likely that one might find companies in each industry that do not fit the general characteristics described.

We distinguished two groups of Polish producers:

- Natives of prosumption comprise producers in industries in which activity on the Internet is inherent. This group engages in a continuous contact with consumers and discusses various solutions to problems involved in copyright; this group exhibits a wider acceptance of copyright infringement and more frequently undertakes proprosumption marketing activities. Video game producers and comic publishers are natives of prosumption; however, comic publishers may be included as part of this group not because of their adaptation to the digital world but because of the nature of their industry. Pro-prosumption activities here are "innate" and have been practiced by publishers since the beginning of their operations. In Poland, for quite some time, comics were published by fans and for fans; thus, prosumption was "the original sin" of the entire comic industry.

- Tourists of prosumption comprise producers in industries that have had difficulty adapting to the nature of the digital world, i.e., television, film, and music producers. This lack of adjustment occurs in various ways; some companies try to continue to operate according to their own offline rules, employing distribution and marketing 
principles typical of the traditional analog world. If there are pro-prosumption activities, it is only the result of an unwilling acceptance of new realities, i.e., those characteristic of the Internet. It has to be emphasized that the term "tourist" is used here in a metaphorical way. Even if they undertake the task of stimulating prosumption, they are likely to dabble in such activities briefly and then return to traditional activities.

It is evident that producers adjust to the world of Web 2.0 to varying degrees. Natives of prosumption use various Web 2.0 tools at an advanced level in order to stimulate prosumption. Tourists do not use them at all or do so more rarely and with worse results. Natives stimulate the use of such tools by consumers and prosumers; by contrast, tourists fail to do that.

The respondents' statements revealed that the tourists live in the past in terms of understanding the phenomenon of prosumption, communicating with consumers, and undertaking specific pro-prosumption activities. All of the dimensions of prosumption are treated as belonging to the future, and prosumption is referred to as something that "is going to gain in importance and power," but is something to be considered in several, or several dozen, years. Film, television, and music producers indiscriminately treat all emerging proprosumption activities as unprecedented, special, and unique. If they begin to build the consumers' engagement in an untypical way and make consumers work for a title, they (producers) themselves observe these activities as if they are something revolutionary. This is not a coincidence since film, TV, and music producers undertake pro-prosumption activities sporadically.

The situation is different in the case of video games and comics. Natives treat prosumption as something that is already happening; they also undertake more pro- 
prosumption activities both in communicating with consumers and in other forms of engaging them. This is not a question of the future but the present, which obviously does not exclude that the described processes will intensify.

Decidedly, an orientation toward prosumption is highly present in the video game industry. This industry is open to consumers, as is manifested in producers' participation in conventions, and invitations extended to gamers to special meetings at companies' head offices. Game producers encourage consumers to engage in creative acts by allowing them access to the resources and tools necessary in making amateur productions; often, in this spirit, they ignore copyright infringement.

As aforementioned, the pro-prosumerism of the comics sector results from the specific history of this market. To explain the prosumer orientation of the game industry, global nature of the produced content is relevant. Among other things, we studied producers of games who have been successful worldwide and have established a position in the global market (Frąckiewicz, 2013). In the context of Polish popular culture, such a position is only possible in the case of games; other pop culture genres find it decidedly harder to reach global market. The success that has been achieved by the game industry may certainly be connected with its use of the latest marketing techniques (Frąckiewicz, 2013), including treating consumers as communities.

\section{Conclusions}

The conducted research has revealed the degree to which Polish pop culture producers opt for so-called prosumption. As was stated in the introduction, the researchers did not use representative sample of the researched population. This was an exploratory assignment, and the goal was to gain an insider's perspective into the extent to which the Polish pop culture industry engages in pro-prosumption activities and what this means for the theory of prosumer 
capitalism.

Overall, observing all sectors, it may be argued that Polish pop culture producers engage in these practices at a low level (despite the positive activities of game producers), compared with producers in the United States and Western Europe. The presented model for pro-prosumption activities in the pop culture industry was constructed based on an analysis of the literature on prosumption in the United States and Western Europe. Many examples included in the model went unmentioned by the respondents; attempts to introduce these examples into conversation were unsuccessful. Producing games based on mods created by gamers (M1, S2), stimulating cosplay practices (M1, S2), organizing trips to places connected with pop texts (M2, S3), employing rich transmedia storytelling (M3, S1), and using cliffhangers (M3, S2) or micropayment techniques (M3, S3) are all examples of practices that are non-existent in the Polish pop culture industry.

Obviously, Polish producers follow foreign marketers, sometimes quite successfully; however, the best developed are the "standard" and "simplest" pro-prosumption measures, which rely on social media. The Polish pop industry remains too "scared" to encourage creative activities among consumers through stimulating strong emotional engagements by using the previously discussed practices or through softening their stance on copyright infringement (with the exception of game producers)

Producers differ in regard to pro-prosumer activities. Just as bottom-up activities undertaken by various communities of prosumers differ, the same may be said about the differences between producers. In order to specify and develop the theory of prosumer capitalism, the considerations on the prosumer orientations of producers should be each time specified. With the formulation of a general framework for prosumer capitalism, reflecting on how and to what extent this framework can indicate activities by various companies is warranted. One may consider, among other things, the intensity to which such companies 
have adapted to conditions to function in the world of Web 2.0.

The article discusses Polish producers of popular culture. The results of the project cannot be applied directly to the markets of other countries - when investigating into the differences between producers, many contextual factors have to be taken into account. Differences in prosumer orientations may result from differences in cultural, political, social, and historical context. This is a field in which further study is necessary. Producers functioning within different industries must be compared in a more detailed way. In other words, the various mechanisms of prosumption remain to be revealed.

To conclude, although the executives' statements say a lot about the orientations towards consumer co-creation, they also say something about the relations that producers have with consumers and prosumers. In the introduction, it was indicated that the shape that bottom-up prosumer activities take is to a large extent dependent on how they are stimulated by corporations. Although the presented empirical material does not pertain to explaining how consumers respond to companies' actions, it still provides a picture of what happens at the interface of consumers and producers. In prosumer capitalism the rising of prosumer trends is both a matter of bottom-up prosumer activities and the top-down activities of industries.

\section{References:}

Antonio RJ (2015) Is Prosumer Capitalism on the Rise? The Sociological Quarterly 56(3): 472-483.

Banks JA (2013) Co-creating Videogames. London: Bloomsbury.

Baym NK and Burnett R (2009) Amateur experts: International fan labour in Swedish independent music. International Journal of Cultural Studies 12(5): 433-449.

Beer D and Burrows R (2010) Consumption, Prosumption and Participatory Web Cultures: An introduction. Journal of Consumer Culture 10(1): 3-12. 
Beer D (2013) Popular Culture and New Media: The Politics of Circulation. New York: Palgrave Macmillan.

Brooker W (2002) Using the Force: Creativity, Community and Star Wars Fans. New York and London: Continuum.

Brooker W (2007) Everywhere and nowhere: Vancouver, fan pilgrimage and the urban imaginary. International Journal of Cultural Studies 10(4): 423-444.

Campbell C (2005) The Craft Consumer: Culture, Craft and Consumption in a Postmodern Society. Journal of Consumer Culture 5(1): 23-42.

Cova B, Kozinets RV, Shankar A (eds) (2007) Consumer Tribes. London: ButterworthHeinemann.

Deuze M (2007) Convergence culture in the creative industries. International Journal of Cultural Studies 10(2): 243-263.

Frąckiewicz S (2013) Wielka gra małych gier [Big Game of Little Games]. Polityka [Politics].

Available at: http://www.polityka.pl/tygodnikpolityka/kultura/1534247,1,swiatowe-sukcesypolskich-gier.read.

Ito M (2007) Technologies of the Childhood Imagination: Media Mixes, Hypersociality, and Recombinant Cultural Form. In: Karaganis J (ed) Structures of Participation in Digital Culture, New York: Social Science Research Council, 31-34.

Jenkins H (2004) The cultural logic of media convergence. International Journal of Cultural Studies 7(1): 33-43.

Kozinets RV (2010) Netnography: Doing Ethnographic Research Online. London, Thousand Oaks and New Delhi: SAGE Publications. 
Long GA (2007) What Is Transmedia Storytelling: Business, Aesthetics and Production at the Jim Henson Company.

Available at: http://cms.mit.edu/research/theses/GeoffreyLong2007.pdf.

Meisler A (1995) TELEVISION; When J. R. Was Shot The Cliffhanger Was Born. The New York Times. Available at: http://www.nytimes.com/1995/05/07/arts/television-when-j-r-wasshot-the-cliffhanger-was-born.html?pagewanted=all

Morrow G (2009) Radiohead's Managerial Creativity. Convergence: The International Journal of Research into New Media Technologies 15(2): 161-176.

Nakajima S (2012) Prosumption in art. American Behavioral Scientist 56(4): 550-569.

Postigo H (2007) Of Mods and Modders: Chasing Down the Value of Fan-Based Digital Game Modifications. Games and Culture 2(4): 300-313.

Ritzer G and Jurgenson N (2010) Production, Consumption, Prosumption: The nature of capitalism in the age of the digital 'prosumer'. Journal of Consumer Culture 10(1): 13-36.

Ritzer G, Dean P and Jurgenson N (2012) The Coming of Age of the Prosumer. American Behavioral Scientist 56(4): 379-398.

Siuda P (2012) Kultury prosumpcji [Prosumption Cultures]. Warsaw: ASPRA-JR.

Siuda P, Bomba R, Kaminska M, Stunza GD, Szylar A, Troszynki M and Zaglewski T (2013) Prosumption in the Pop Industry: An Analysis of Polish Entertainment Companies. Warsaw: Collegium Civitas Press.

Tapscott D, Williams A (2010) Wikinomics: How Mass Collaboration Changes Everything. New York: Penguin Group.

Taylor JR (2009) Convention Cosplay: Subversive Potential in Anime Fandom. Available at: http://circle.ubc.ca/handle/2429/7116. 
Terranova T (2000) Free Labour: Producing Culture for the Digital Economy. Social Text 18: $33-58$.

Théberge P (2005) Everyday fandom: Fan clubs, blogging, and the quotidian rhythms of the internet. Canadian Journal of Communication 30(4): 485-502. 